\title{
miRNA zaangażowane w proces starzenia i kiełkowania nasion
}

\author{
miRNAs involved in the seed ageing and germination process
}

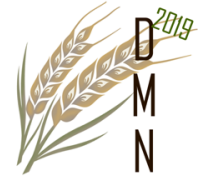

\author{
Marta Puchta $\bowtie$
}

\author{
Krajowe Centrum Roślinnych Zasobów Genowych, \\ Instytut Hodowli i Aklimatyzacji Roślin - Państwowy Instytut Badawczy w Radzikowie, \\ $\bowtie$ e-mail: m.puchta@ihar.edu.pl
}

\begin{abstract}
Starzenie nasion jest procesem prowadzącym do nieodwracalnych zmian powodujących utratę ich wartości siewnej w czasie. W proces ten zaangażowanych jest wiele wzajemnie powiązanych zmian molekularnych, biochemicznych, fizjologicznych oraz metabolicznych. W związku z degradacją środowiska naturalnego wymagana jest intensywna ochrona gatunkowa roślin. Zachowanie zdolności do kiełkowania nasion odgrywa kluczową rolę w ochronie bioróżnorodności gatunkowej. Przeprowadzone dotychczas badania wskazują na udział miRNA w dynamicznym procesie kiełkowania nasion. Jednak niewiele wiadomo na temat zagadnień dotyczących regulacji miRNA i ich genów docelowych, które są potencjalnie ważnymi czynnikami przyczyniającymi się do starzenia nasion podczas długotrwałego przechowywania.
\end{abstract}

Praca obejmuje przegląd wybranej literatury dotyczącej badania roli miRNA w regulacji procesów zaangażowanych w starzenie i kiełkowanie nasion.

\section{Słowa klucze: miRNA, starzenie nasion, żywotność, kiełkowanie}

\begin{abstract}
The ageing of seeds is a process that leads to irreversible changes that cause the loss of seed value over time. Many interrelated molecular, biochemical, physiological and metabolic processes are involved in it. The degradation of the natural environment requires intensive plant species protection. Preserving germination capacity plays a key role in protecting the biodiversity damaged by genetic erosion. The studies conducted so far show that miRNAs are involved in the dynamic germination process of seeds. However, little is known about the state of specific miRNA regulations and their targets. These, are potentially important factors contributing to the ageing of seeds during longterm storage. germination germination
\end{abstract}

This review includes literature review of research concerning the role of miRNA in the regulation of processes leading to seed ageing and germination.

Key words: miRNA, seed aging, vitality, germination

\section{Wstęp}

Żywotność nasion miała znaczenie dla ludzkości od czasów rewolucji neolitycznej, kiedy nastąpiło przejście od magazynowania żywności do jej produkcji, a część zbiorów musiała zostać zachowana na następny sezon. Pierwsze informacje dotyczące starzenia się nasion zostały podane już w starożytnej Grecji, kiedy Teofrast z Erezos zauważył, że przechowywanie nasion $\mathrm{w}$ przewiewnych miejscach na dużych wysokościach przedłuża ich żywotność. Ponadto zaobserwował, że nasiona cebuli tracą żywotność znacznie szybciej, niż nasiona prosa. W I wieku Lucjusz Lunius Moderatus Columella dostrzegł negatywny wpływ wilgotności na proces przechowywania nasion. W średniowieczu Ibn al-'Awwām stworzył rozprawę naukową pt. „Kitāb al-filā-ḥah”, zawierający informacje, jak prawidłowo przechowywać nasiona. Francuski botanik Henri-Louis Duhamel du Monceau w XVIII wieku zaobserwował zróżnicowanie w żywotności nasion w zależności od gatunku rośliny (Priestley, 1986).

Celem pracy jest przegląd wybranej literatury dotyczącej regulacyjnej roli miRNA w szlaki metaboliczne związane $\mathrm{z}$ procesem starzenia i kiełkowania nasion.

\section{Starzenie Nasion}

Starzenie jest to długotrwały i nieodwracalny proces zachodzący w rozwoju osobniczym żywych organizmów. Proces ten polega na postępujących w czasie zmianach w komórkach, których ostatecznym skutkiem jest śmierć organizmu. Długość życia to czynnik, który znacząco 
różnicuje organizmy (Roberts, 1979). U roślin jego rozpiętość jest znacznie większa, niż u zwierząt, przykładem czego są osobniki Pinus aristata w White Mountain w Kalifornii, których wiek szacuje się na około 5000 lat (Currey, 1965). W 1877 r. znaleziono „próbkę wiedeńską”, którą przechowywano $\mathrm{w}$ hermetycznie zamkniętych pojemnikach w temperaturze $10-15^{\circ} \mathrm{C}$ i wilgotności $3,13 \%$ przez ponad 110 lat. Wśród próbek znajdowały się nasiona jęczmienia wykazujące $90 \%$ żywotności, owsa $81 \%$, podczas gdy pszenica posiadała niską zdolność kiełkowania, a żyto całkowicie straciło żywotność (Steiner i Ruckenbauer, 1995). Nasiona większości gatunków roślin mogą przetrwać nawet do kilku tysięcy lat, np. nasiona Nelumbo nucifera, których wiek był datowany na ok. 1300 lat, miały zdolność kiełkowania na poziomie 84\% (Shen-Miller, 2002).

Starzenie nasion prowadzi do nieodwracalnych zmian powodujących utratę wartości siewnej w czasie. W efekcie starzenia nasiona tracą wigor oraz żywotność. W 1876 r. Nobbe stwierdził występowanie różnic $\mathrm{w}$ zakresie kiełkowania i wzrostu w obrębie partii materiału siewnego nazywając zjawisko,, siłą napędową", czyli,, wigorem nasiennym" (Sun i in., 2007). W 1976 r. stowarzyszenie ISTA (ang. International Seed Testing Association) opracowało definicję wigoru nasion jako sumę tych właściwości nasion, które określają poziom ich aktywności i zachowania się podczas kiełkowania i wzrostu siewek. Zaobserwowano, iż spadek wigoru nasion następuje dużo wcześniej niż spadek zdolności kiełkowania; jest to związane z procesem starzenia, który rozpoczyna się już w fazie przedżniwnej. O poziomie wigoru nasion decydują trzy główne czynniki: aspekt genetyczny, środowisko rozwoju i warunki przechowywania (Sun i in., 2007).

$\mathrm{W}$ proces starzenia nasion zaangażowanych jest wiele wzajemnie regulujących się mechanizmów na poziomie molekularnym, fizjologicznym, biochemicznym i metabolicznym (Boczkowska i in., 2019; Sarkar Das i in., 2018). Mimo wielu prób poznania przyczyn starzenia się nasion nie wyjaśniono, które czynniki mają zasadniczy wpływ na długość życia nasion oraz jakie mechanizmy prowadzą do utraty żywotności. Dotychczasowe badania wskazują, że $\mathrm{w}$ proces ten zaangażowane są czynniki zewnętrzne i wewnętrzne.

Do najważniejszych czynników egzogennych należą: warunki pogodowe w czasie wzrostu rośliny i zbioru nasion, technologia przygotowania nasion do przechowywania oraz warunki przechowywania. W oparciu o odporność nasion na odwodnienie, podzielono je na trzy grupy: (I) nasiona,, orthodox" wykazujące tolerancję na odwadnianie poniżej 5\% wilgotności; oraz (II) nasiona,, recalcitrant", które wykazują brak tolerancji na odwadnianie i giną w trakcie suszenia do $20-50 \%$ oraz (III) ,subothodox" nasiona z umiarkowaną tolerancją na suszenie (Ellis et al., 1990; Roberts, 1979). Zgodnie z zasadą Harringtona, żywotność nasion typu,, orthodox" podwaja się po obniżeniu temperatury o $5^{\circ} \mathrm{C}$ i obniżeniu wilgotności o 1\% (Harrington, 1963).

Wraz $\mathrm{z}$ postępującym procesem starzenia w błonach komórkowych nasion dochodzi do pojawienia się nieciągłości. Ponadto wzrasta częstotliwość aberracji chromosomowych oraz mutacji genowych. Wraz ze spadkiem wigoru nasion, rbosomalne RNA 28S, i 18S rRNA ulegają stopniowej degradacji (Sun i in., 2007). Wykazano także, że degradacja RNA i starzenie się nasion soi przebiega $\mathrm{w}$ podobnym tempie (Fleming $\mathrm{i}$ in. 2017).

Ze względu na różną żywotność nasion w procesie naturalnego starzenia, wielu naukowców prowadzi badania w warunkach sztucznych, w których przyspiesza się naturalny proces starzenia poprzez podniesienie temperatury i wilgotności. Według dostępnych danych literaturowych symulacja ta nie odzwierciedla jednak zmian zachodzących podczas starzenia się suchych nasion (Gutiérrez i in., 1993; Neto i in., 2016).

Prowadzono wiele badań dotyczących starzenia i kiełkowania nasion (Priestley, 1986; Ventura i in., 2012; Wang i in., 2011), brak jednak odpowiedzi na pytanie: jakie konkretnie mechanizmy molekularne i w jaki sposób odpowiadają za starzenie i kiełkowanie nasion poddanych długotrwałemu przechowywaniu. Odkrycie małych, niekodujących RNA, które zaangażowane są $\mathrm{w}$ wiele procesów rozwojowych, przełożyło się na wzrost zainteresowania ich rolą w procesach kiełkowania i starzenia się nasion.

\section{miRNA}

Małocząsteczkowe RNA (ang. small RNA, sRNA) obejmują kilka klas krótkich niekodujących RNA: miRNA (mikroRNA, ang. microRNA, ), siRNA (małe interferujące RNA, ang. small interfering $R N A$ ) oraz piRNA (niekodujące cząsteczki RNA wykazujące aktywność małych regulatorowych RNA, ang. piwi-interacting RNA), które regulują ekspresję genów na poziomie potranskrypcyjnym (Wang i in., 2011). Liczba sRNA w komórkach roślinnych jest na tyle duża, aby sugerować regulacyjną rolę tych cząsteczek (Wang i in., 2011). Najlepiej scharakteryzowaną klasą sRNA roślinnych jest miRNA (Wang i in., 2011). 
MikroRNA (miRNA) to około 21 nukleotydowe endogeniczne niekodujące RNA, które odgrywają ważną rolę w potranskrypcyjnej regulacji ekspresji genów. W wyniku działania miRNA dochodzi do przecięcia lub blokowania translacji docelowych mRNA (Hu i in., 2016; Rogers and Chen, 2013; Wang $i$ in., 2019).

\section{Biogeneza miRNA}

Biogeneza miRNA jest procesem wieloetapowym (ryc.1). Dojrzałe miRNA powstaje z własnych podjednostek transkrypcyjnych. Przy udziale polimerazy II RNA dochodzi do transkrypcji genów MIR i powstania pierwotnego transkryptu pri-miRNA. W kolejnym etapie generowany jest prekursor miRNA (pre-miRNA) o strukturze "spinki do włosów" (ang. hairpin RNA, hpRNA). Proces powstania pre-miRNA zachodzi przy udziale kompleksu białka serrate (SE), hyponastic leaves (HYL-1) oraz dicer like 1 (DCL1) (Reinhart, 2002). Niskocząsteczkowa metylotransferaza HEN1 metyluje wystające końce 3' i transportuje dupleks miRNA/miRNA* z jądra do cytoplazmy. Następnie dochodzi do enzymatycznego rozszczepienia dupleksu na dwie nici. Jedna $\mathrm{z}$ nich (nić prowadząca - miRNA) jest włączana do kompleksu wyciszającego RNA (ang. RNA-induced silencing complex, RISC). Wbudowane dojrzałe miRNA ukierunkowuje kompleks RISC na mRNA zawierające gen docelowy prowadząc do jego degradacji. W rezultacie kompleks RISC negatywnie reguluje ekspresję docelowego mRNA (Wang $\mathrm{i}$ in., 2011). Koniec 5' miRNA, zwłaszcza w pozycji 2-8 nukleotydów jest kluczowy dla interakcji z transkryptem genu docelowego (Brennecke i in., 2005). Miejsce docelowe wykazuje prawie doskonałą komplementarność z sekwencją miRNA. Większość docelowych mRNA jest przecinana przez RISC, chociaż istnieją przykłady gdzie translacja mRNA thumiona jest bez rozcięcia (Chen, 2004). Regulacyjna rola miRNA została wykazana dla kluczowych etapów rozwoju korzeni, pędów, liści oraz kwiatów. Dodatkowo uczestniczą one $\mathrm{w}$ odpowiedzi na fitohormony, składniki odżywcze i stresy środowiskowe (Wang $\mathrm{i}$ in., 2011).

\section{Roślinne miRNA $\mathrm{i}$ ich rola $\mathrm{w}$ regulacji ekspresji genów docelowych}

Dotąd scharakteryzowano 14197 dojrzałych miRNA roślinnych i zdeponowano je w ogólnodostępnej bazie miRBase (miRBAse ver.22.1) [http:// www.mirbase.org/]. Większość $\mathrm{z}$ nich stanowią miRNA pochodzące z kukurydzy, ryżu i Arabidopsis thaliana (Wang $\mathrm{i}$ in., 2011). Wang $\mathrm{i}$ in.
(2011) potwierdzili obecność 115 znanych miRNA oraz wykryli 167 nowych miRNA w kiełkujących nasionach kukurydzy. Badania rośliny dwuliściennej Nelumbo nucifera potwierdziły obecność 145 znanych i wykazaly 78 nowych miRNA (Hu i in., 2016). Sarkar Das i in. (2018) podczas badań nad kiełkującymi ziarniakami $A$. thaliana zidentyfikowali 58 znanych miRNA należących do 30 różnych rodzin.

U Arabidopsis thaliana, piętnaście spośród zidentyfikowanych miRNA oraz ich geny docelowe wykazywały istotne różnice w poziomie ekspresji w stanie suchym oraz po 12, 24 i 48 godzinach imbibicji nasion. Zasugerowano, że dynamika zmian ekspresji miRNA i ich genów docelowych (tab. 1) ma wpływ na regulację kiełkowania nasion A. thaliana (Sarkar Das i in., 2018). miR417 poprzez oddziaływanie na geny $C 2$ domain- containing protein, $R d R P$, $S N F A R F$ ujemnie reguluje kiełkowanie nasion pod wpływem stresu zasolenia, natomiast nadekspresja miR402 którego celem jest gen $D M L 3$, zwiększa zdolność kiełkowania nasion w warunkach nadmiernego zasolenia (Jung and Kang, 2007; Kim i in., 2010). Z kolei nadekspresja miR160 powoduje zmniejszenie czułości reakcji na kwas abscysynowy (ang. abscisic acid, ABA) podczas kiełkowania (Hu i in., 2016). Ponadto Mallory i in. (Mallory i in., 2005) wykazali rolę miR160 w regulacji ekspresji czynnika odpowiedzi auksynowej ARF17 (ang. auxin response factor) w A. thaliana. Geny z rodziny GAMYB są zaangażowane w transdukcję sygnału giberelinowego (GA) w aleuronie, a ponadto biorą udział w aktywacji promotora $\alpha$-amylazy oraz innych genów regulowanych przez GA niezbędnych do mobilizacji rezerw endospermy. Podczas nadekspresji miR159 zaobserwowano zmniejszenie poziomu MYB33, opóźniającego czas kwitnienia A. thaliana (Millar, 2005). Gen LEC1 (NF-YB9) jest kluczowym regulatorem dojrzewania nasion u A.thaliana. Mutacje prowadzące do utraty funkcji $L E C 1$ powodują poważne nieprawidłowości w rozwoju zarodków i nasion, podczas gdy nadekspresja $L E C 1$ powoduje przejście ze stanu wegetatywnego do embrionalnego i akumulację związków zapasowych w tkankach. Ponadto stwierdzono, że niektóre geny $\mathrm{z}$ rodziny $N F-Y$ są zaangażowane w kontrolę kwitnienia, odporność na suszę oraz rozwój korzeni (Mu i in., 2013). Wykazano, że nadekspresja miR169, regulującego działanie rodziny genów NF-YA spowodowała nadwrażliwość na ABA podczas kiełkowania (Mu i in., 2013). Oksydaza $L$-askorbinowa, która może usuwać reaktywne formy tlenu produkowane podczas stresu oksydacyjnego, jest genem 
docelowym dla miR408. Hu i in. (2016) zaobserwowali że, wszystkie miRNA z rodziny miR408 różniły się istotnie poziomem ekspresji w poszczególnych stadiach kiełkowania, jednoznacznie wskazując na zaangażowanie miR408 w przebieg tego procesu (Hu i in., 2016).

Wykazano, że mutacje w genie $A R F 10$ (czynnik odpowiedzi auksynowej 10 , ang. auxin response factor 10), będącym genem regulowanym przez miR160, np. $A B I 3$ powodują wady rozwojowe: ząbkowanie liści, deformacje łodygi i kwiatów oraz skręcanie łuszczyn w efekcie działania ekspresji genów indukujących ABA (Liu i in., 2007). Natomiast miR159 reguluje rozwój kwiatów, płodność i kiełkowanie nasion poprzez obniżanie poziomu ekspresji czynnika transkrypcyjnego MYB (Reyes and Chua, 2007).

Znokautowanie genu kodującego GAMYB u ryżu powoduje wady rozwojowe pylników i pyłku. Nadekspresja miR159 wpływała na karłowacenie pylników u ryżu oraz męską sterylność u rzodkiewnika (Achard i in., 2008).

Tabela 1

Table 1

miRNA oraz geny docelowe 0 istotnych różnicach $w$ poziomie ekspresji zidentyfikowane u A. thaliana (Sarkar Das i in., 2018; Millar, 2005) .

\begin{tabular}{cc}
\hline miRNA & Geny docelowe \\
\hline $\operatorname{miR} 165$ & PHB, ATHB15 \\
$\operatorname{miR} 166$ & $P H B, A T H B 15$ \\
$\operatorname{miR} 172$ & $A P 2$, TOE1, TOE2, TOE3 \\
$\operatorname{miR} 160$ & $A R F 10, A R F 16, A R F 17$ \\
$\operatorname{miR} 156$ & $S P C$ \\
$\operatorname{miR} 157$ & $S P C$ \\
$\operatorname{miR} 164$ & NAC1, CUC1, CUC2 \\
$\operatorname{miR} 169$ & $N F-Y$ \\
$\operatorname{miR} 161$ & $P P R$ \\
$\operatorname{miR} 399$ & $P H O 2$ \\
$\operatorname{miR} 824$ & $A G C 16$ \\
$\operatorname{miR} 834$ & $D M C 2, C I P 1$ \\
$\operatorname{miR} 854$ & $R 3 H$ \\
$\operatorname{miR} 2112$ & $E R G 4, P R R$ \\
$\operatorname{miR} 159$ & $M Y B 33$ \\
\hline
\end{tabular}

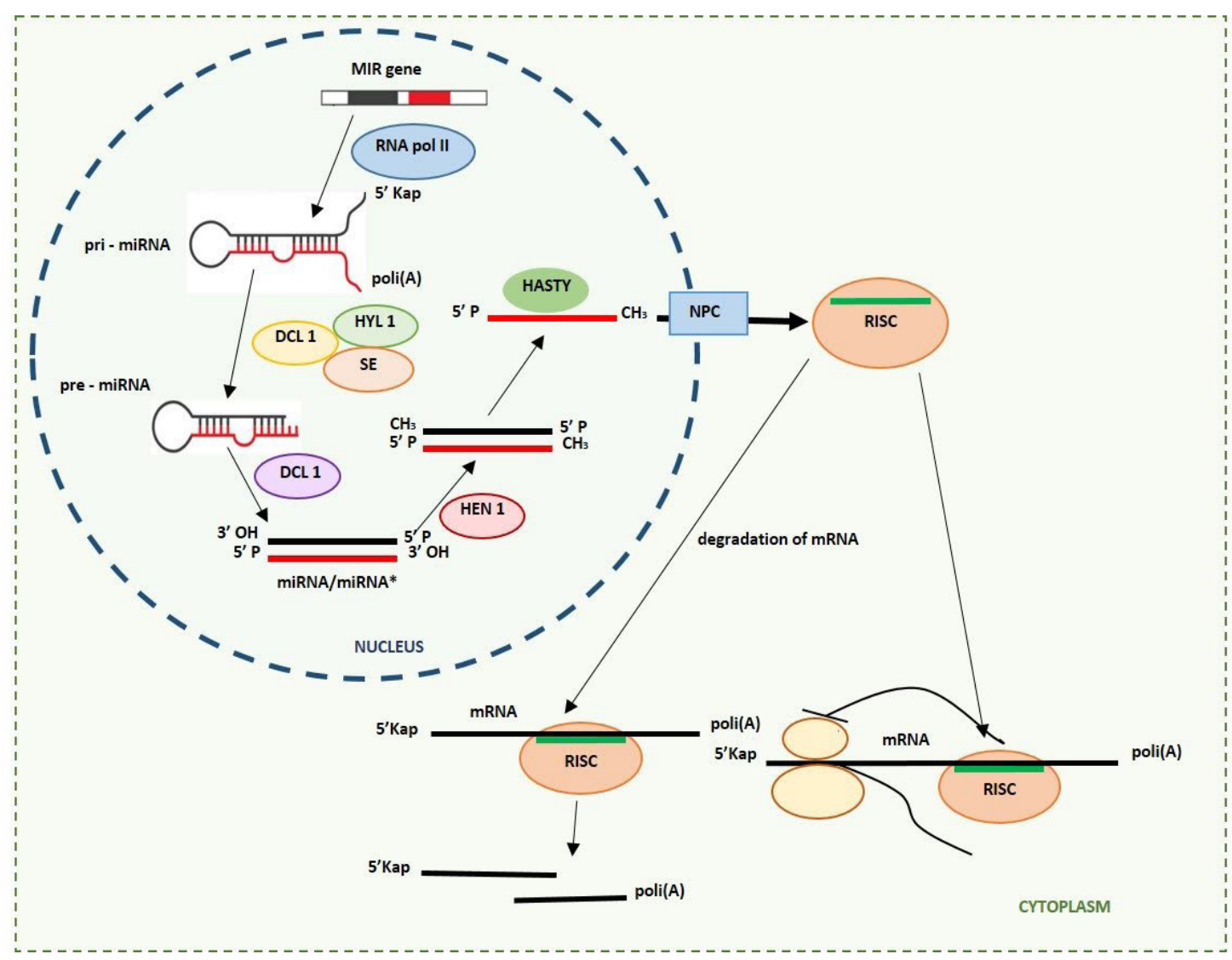

Rys. 1. Schemat biogenezy roślinnych miRNA.

RNA pol II, RNA II polimeraza; DCL1, dicer like I; HYL1, hyponastic leaves 1; SE, białko serrate; HEN1, wzmaczniacz transkrypcji HUA; HASTY, białko HASTY 1; RISC, kompleks wyciszający RNA (według: Rogers i in. 2013; Wang i in. 2019).

Fig. 1. miRNA biogenesis in plants. 
W wyniku sekwencjonowania degradomu z nasion $N$. nucifera wykazano obecność genów docelowych: SPL, NAC, ARF, TIR like, NFY, GAMYB, LAO odpowiednio dla miR156, miR164, miR160, miR393, miR169, miR159 oraz miR408. Zidentyfikowane geny stanowiły głównie czynniki transkrypcyjne (Hu i in., 2016). Białka PPR (ang. pentatricopeptide repeat) wpływające na ekspresję genów w mitochondriach i chloroplastach u $N$. nucifera są regulowane przez niektóre miRNA: miR168, miR2673 oraz nowe miR7 i miR40 (Wang i in., 2011). Hu i in. (2016) podczas badań kiełkujących nasion $N$. nucifera potwierdzili ekspresję miR168, miR2673 oraz zidenty fikowali nowe miR7 i miR40, które regulują ekspresję genów kodujących powstawanie białek PPR, co może sugerować regulacje przez nie przebiegu poszczególnych etapów fotosyntezy oraz gromadzenia się lipidów podczas kiełkowania nasion w $N$. nucifera. Geny $N F-Y$ zaangażowane są $\mathrm{w}$ regulację różnych procesów rozwojowych i reakcje na stres. $N F-Y$ (jądrowy czynnik $Y$, ang. nuclear transcription factor $Y$ ), który ma wpływ na rozwój nasion u wielu gatunków, jest genem docelowym dla miR169. W wyniku analiz degradomu zidentyfikowano NFYA2, NFYA3 i NFYA10 będące docelowymi genami miR169 u $N$. nucifera (Hu i in., 2016).

Przedstawiony w artykule rys literaturowy wskazuje na udział dużej liczby miRNA w dynamicznym procesie kiełkowania nasion. Zaangażowanie licznych rodzin miRNA w proces kiełkowania nasion może zatem wskazywać iż odgrywają one rolę także $\mathrm{w}$ procesie starzenia nasion. Pomimo zwiększającego się stanu wiedzy na temat regulacji procesów życiowych przez miRNA nadal niewiele wiadomo na temat wpływu miRNA i ich genów docelowych na procesy starzenia nasion (Hu i in., 2016). W Krajowym Centrum Roślinnych Zasobów Genowych, IHAR-PIB prowadzone są badania obejmujące tematykę starzenia i kiełkowania nasion poddanych długotrwałemu przechowywaniu, między innymi w ramach projektu badawczego NCN Preludium nr 2019/35/N/NZ9/01046 (2020 - 2023), oraz pracy doktorskiej realizowanej przez Autorkę artykułu; promotorem pracy jest dr hab. Maja Boczkowska natomiast promotorem pomocniczym - dr Jolanta Groszyk.

\section{Podsumowanie}

Dogłębne poznanie przyczyn procesu starzenia i zachowanie zdolności kiełkowania nasion odgrywa kluczową rolę w ochronie różnorodności biologicznej w bankach genów. Nasiona stanowią idealny model do analizy procesów starzenia, ich przyczyn oraz zachowania zdolności do kiełkowania. Dotychczas przeprowadzone badania wskazują na udział miRNA w dynamicznym procesie kiełkowania i starzenia nasion. Obecnie scharakteryzowano 14197 dojrzałych miRNA roślinnych i zdeponowano je w ogólnodostępnej bazie miRBase, jednak nadal ich rola $\mathrm{w}$ procesach starzenia i kiełkowania nasion nie została szczegółowo zdefiniowana. Autorzy w literaturze światowej sugerują konieczność kontynuacji badań dotyczących wpływu miRNA na procesy starzenia i kiełkowania. Dalsze badania miRNA i ich genów docelowych w nasionach umożliwią głębsze zrozumienie sieci regulacyjnej, w której uczestniczą miRNA podczas procesu starzenia i kiełkowania. Przyczynią się one do zwiększenia wiedzy na temat sposobów utrzymania efektywnego funkcjonowania komórek przez długi czas.

\section{Literatura}

Achard, P., Renou, J. P., Berthomé, R., Harberd, N. P., Genschik, P., (2008). Plant DELLAs Restrain Growth and Promote Survival of Adversity by Reducing the Levels of Reactive Oxygen Species. Curr. Biol. 18, 656-660. https://doi.org/10.1016/j.cub.2008.04.034

Boczkowska, M., Rucińska, A., Targońska-Karasek, M., Olszak, M., Niedzielski, M., Rakoczy-Trojanowska, M., (2019). Starzenie się nasion - złożony problem banków genów. Praca przeglądowa. Agron.Sci. 73, 15-26. https:// doi.org/10.24326/asx.2018.4.2

Bray, C. M., Ashraf, M., Davison, P. A., (1993). Molecular markers of seed quality. In: Come D, Combineau F, eds, Proceedings of the Fourth International Workshops on Seeds. ASFIS, Paris 887-896.

Brennecke, J., Stark, A., Russell, R. B., Cohen, S.M., (2005). Principles of MicroRNA-Target Recognition. PLoS Biol. 3, e85. https://doi.org/10.1371/journal.pbio.0030085

Chen, X., (2004). A MicroRNA as a Translational Repressor of APETALA2 in Arabidopsis Flower Development. Science 303, 2022-2025. https://doi.org/10.1126/science.1088060

Currey, D. R., (1965). An Ancient Bristlecone Pine Stand in Eastern Nevada. Ecology 46, 564-566. https://doi. org/10.2307/1934900

Ellis, R. H., Hong, T. D., Roberts, E. H., (1990). An Intermediate Category of Seed Storage Behaviour?: I. COFFEE. J Exp Bot 41, 1167-1174. https://doi.org/10.1093/jxb/41.9.1167

Gutiérrez, G., Cruz, F., Moreno, J., González-Hernández, V. A., Vázquez-Ramos, J. M., (1993). Natural and artificial seed ageing in maize: germination and DNA synthesis. Seed Sci. Res. 3, 279-285. https://doi.org/10.1017/ S0960258500001896

Harrington, J., (1963). Practical instructions and device on seed storage. Proceedings of the International Seed Testing Association. 28, 989-994. 
Hu, J., Jin, J., Qian, Q., Huang, K., Ding, Y., (2016). Small RNA and degradome profiling reveals miRNA regulation in the seed germination of ancient eudicot Nelumbo nucifera. BMC Genomics 17, 684. https://doi.org/10.1186/ s12864-016-3032-4

Jung, H. J., Kang, H., (2007). Expression and functional analyses of microRNA417 in Arabidopsis thaliana under stress conditions. Plant Physiol. Biochem. 45, 805-811. https:// doi.org/10.1016/j.plaphy.2007.07.015

Kim, J. Y., Kwak, K. J., Jung, H. J., Lee, H. J., Kang, H., (2010). MicroRNA402 Affects Seed Germination of Arabidopsis thaliana Under Stress Conditions via Targeting DEMETER-LIKE Protein3 mRNA. Plant Cell Physiol. 51, 1079-1083. https://doi.org/10.1093/pcp/pcq072

Liu,P.P., Montgomery, T.A., Fahlgren, N., Kasschau, K.D., Nonogaki, H., Carrington, J.C., (2007). Repression of AUXIN RESPONSE FACTOR10 by microRNA160 is critical for seed germination and post-germination stages: microRNA in Arabidopsis seed germination. Plant J. 52, 133-146. https://doi.org/10.1111/j.1365-313X.2007.03218.x

Mallory, A. C., Bartel, D. P., Bartel, B., (2005). MicroRNADirected Regulation of Arabidopsis AUXIN RESPON$S E$ FACTOR17 Is Essential for Proper Development and Modulates Expression of Early Auxin Response Genes. Plant Cell 17, 1360-1375. https://doi.org/10.1105/ tpc. 105.031716

Millar, A. A., (2005). The Arabidopsis GAMYB-Like Genes, MYB33 and MYB65, Are MicroRNA-Regulated Genes That Redundantly Facilitate Anther Development. Plant Cell 17, 705-721. https://doi.org/10.1105/tpc.104.027920 miRBAse ver.22.1, n.d.

Mu, J., Tan, H., Hong, S., Liang, Y., Zuo, J., (2013). Arabidopsis Transcription Factor Genes NF-YA1, 5, 6, and 9 Play Redundant Roles in Male Gametogenesis, Embryogenesis, and Seed Development. Mol. Plant. 6, 188-201. https://doi.org/10.1093/mp/sss061

Neto, N. B. M., Ceci Castilho Custódio, Massanori Takaki, (2016). Evaluation of naturally and artificially aged seeds of Phaseolus vulgaris L. https://doi.org/10.13140/ RG.2.1.3093.9283

Priestley, D. A., (1986). Seed aging: implications for seed storage and persistence in the soil. Comstock Associates, Ithaca, N.Y.
Reinhart, B. J., (2002). MicroRNAs in plants. Genes Dev. 16, 1616-1626. https://doi.org/10.1101/gad.1004402

Reyes, J. L., Chua, N. H., (2007). ABA induction of miR159 controls transcript levels of two MYB factors during Arabidopsis seed germination: miR159 regulation of ABA responses during germination. Plant J. 49, 592-606. https://doi.org/10.1111/j.1365-313X.2006.02980.x

Roberts, E. H., (1979). Seed deterioration and loss of viability. Advances in Research and Technology of Seeds 4, 25-42.

Rogers, K., Chen, X., (2013). Biogenesis, Turnover, and Mode of Action of Plant MicroRNAs. The Plant Cell 25, 23832399. https://doi.org/10.1105/tpc.113.113159

Sarkar Das, S., Yadav, S., Singh, A., Gautam, V., Sarkar, A. K., Nandi, A. K., Karmakar, P., Majee, M., Sanan-Mishra, N., (2018). Expression dynamics of miRNAs and their targets in seed germination conditions reveals miRNA-ta-siRNA crosstalk as regulator of seed germination. Sci. Rep. 8, 1233. https://doi.org/10.1038/s41598-017-18823-8

Shen-Miller, J., (2002). Sacred lotus, the long-living fruits of China Antique. Seed Sci. Res. 12, 131-143. https://doi. org/10.1079/SSR2002112

Steiner, A. M., Ruckenbauer, P., (1995). Germination of 110-year-old cereal and weed seeds, the Vienna Sample of 1877. Verification of effective ultra-dry storage at ambient temperature. Seed Sci. Res. 5, 195-199. https://doi. org/10.1017/S0960258500002853

Sun, Q., Wang, J., Sun, B., (2007). Advances on Seed Vigor Physiological and Genetic Mechanisms. Agricultural Sciences in China 6, 1060-1066. https://doi.org/10.1016/ S1671-2927(07)60147-3

Ventura, L., Donà, M., Macovei, A., Carbonera, D., Buttafava, A., Mondoni, A., Rossi, G., Balestrazzi, A., (2012). Understanding the molecular pathways associated with seed vigor. Plant Physiol. Biochem. 60, 196-206. https:// doi.org/10.1016/j.plaphy.2012.07.031

Wang, J., Mei, J., Ren, G., (2019). Plant microRNAs: Biogenesis, Homeostasis, and Degradation. Front. Plant Sci. 10, 360. https://doi.org/10.3389/fpls.2019.00360

Wang, L., Liu, H., Li, D., Chen, H., (2011). Identification and characterization of maize microRNAs involved in the very early stage of seed germination. BMC Genomics 12 , 154. https://doi.org/10.1186/1471-2164-12-154

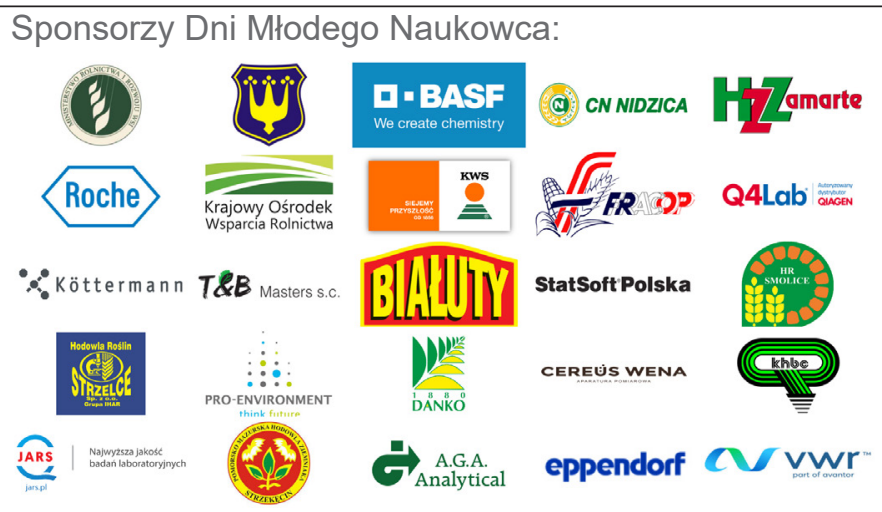

